\title{
Centros at 20: Regulatory Arbitrage and Beyond-An Introduction
}

\author{
Horst Eidenmüller ${ }^{1}$ - Luca Enriques ${ }^{1}$ - Geneviève Helleringer ${ }^{1,2}$. \\ Kristin van Zwieten ${ }^{1}$
}

Published online: 4 September 2019

(c) T.M.C. Asser Press 2019

In its Centros decision (1999), ${ }^{1}$ the then European Court of Justice (now the Court of Justice of the European Union: CJEU) held, in its own words, that a Member State may not 'refuse to register a branch of a company formed in accordance with the law of another Member State in which it has its registered office but in which it conducts no business where the branch is intended to enable the company in question to carry on its entire business in the State in which that branch is to be created, while avoiding the need to form a company there, thus evading application of the rules governing the formation of companies which, in that State, are more restrictive as regards the paying up of a minimum share capital'. ${ }^{2}$ It also noted that because ' $\mathrm{t}$ ] he right to form a company in accordance with the law of a Member State and to set up branches in other Member States is inherent in the exercise, in a single market, of the freedom of establishment guaranteed by the Treaty', 'the fact that a national of a Member State who wishes to set up a company chooses to form it in the Member State whose rules of company law seem to him the least restrictive and to set up branches in other Member States cannot, in itself, constitute an abuse of the right of establishment'. ${ }^{3}$ In short, Centros enabled naked regulatory arbitrage in company law within the EU; and it did so openly and almost emphatically.

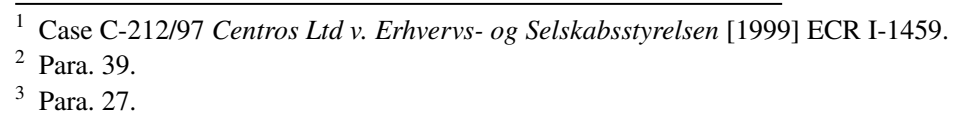

Luca Enriques

luca.enriques@law.ox.ac.uk

Horst Eidenmüller

horst.eidenmueller@law.ox.ac.uk

Geneviève Helleringer

genevieve.helleringer@law.ox.ac.uk

Kristin van Zwieten

kristin.van-zwieten@1aw.ox.ac.uk

1 Faculty of Law, University of Oxford, Oxford, UK

2 ESSEC Business School, Paris, France 
With its bold language, Centros was no less surprising when it was issued than influential ever since: as some of the articles in this issue document, it spurred not only a wave of incorporations in the UK of businesses from other Member States (regulatory arbitrage) but also, as a reaction to that, significant changes to national company laws across the EU (defensive regulatory competition). In the process, it has inspired countless scholarly articles on both its exact meaning and its broader implications - for EU law, for European Member States' company laws, for private international law, and beyond.

This special issue comprises seven articles that relate to Centros, its core themes, and its implications. The papers were presented at the Third Annual Conference of the Oxford Business Law Blog, which was held in Oxford in March 2019, 20 years after the Centros case was decided.

Twenty years add up to many eras in politics, and are a long time in law as well. The European Union itself has changed significantly since 1999: three EU Treaties (Amsterdam, Nice and Lisbon) entered into force after the Centros judgment was issued. The financial crisis prompted a move towards much greater centralization in financial regulation, including in areas adjacent to company law such as securities regulation, and gave the expression 'regulatory arbitrage' a distinctively negative connotation. In the same period, European corporate and insolvency laws have also, to some degree, become more centralized. At the same time, the boundaries of corporate law have changed not only within the EU in order to adapt to the post-Centros world (as explained below), but also more generally, following the tendency of many jurisdictions to tackle social issues through corporate law and corporate governance solutions. ${ }^{4}$ Such a reorientation of corporate law to deal with broader social issues has been a reflection of how, in the last decade or so, the Zeitgeist has become significantly more sceptical about corporations' role in society and the virtues of capitalism, following the financial crisis and the austerity measures that ensued.

So much have the legal framework, the intellectual landscape and the political environment changed that, in reflecting upon Centros today, one cannot help wondering whether a similar decision would still be taken now, had the case not been brought back then. That question is, of course, moot. More relevant is how the current context, including the EU's transition to a community of Member States without the UK among them, may actually influence the CJEU in judging on the legality of a given corporate law rule that the host country may impose on pseudo-foreign companies from other Member States. From this perspective, because Centros ultimately discerns between legitimate and illegitimate obstacles to free movement (i.e., to regulatory arbitrage) based on the Gebhard test $^{5}$ and the general principle against abuse of freedom of establishment, ${ }^{6}$ the Centros case law carries within itself the germs of its own demise as a practically relevant precedent.

\footnotetext{
${ }^{4}$ Pargendler (2016).

${ }^{5}$ Case C-55/94 Reinhard Gebhard v. Consiglio dell'Ordine degli Avvocati e Procuratori di Milano [1995] ECR I-4165.

${ }^{6}$ Centros, paras. 34 and 38.
} 
Anne-Lise Sibony's article reinforces the view that Centros is an anomaly in the history of EU (corporate) law. ${ }^{7}$ By placing Centros within the context of the CJEU's internal market jurisprudence, she shows that an 'alternative Centros' opinion deciding in favour of the Danish authorities would have been as well grounded in its precedents as the 'actual' Centros, specifically with regard to how the CJEU has used the general prohibition on abuse of EU law in similar contexts. Her analysis also highlights one peculiarity of the Centros decision: as she puts it, with Centros the Court 'encouraged regulatory competition in company law as in no other field of law'. In Sibony's account, the formal justification for this attitude towards regulatory arbitrage is the Court's long-held view that '[i]t is always for the home state to define who is a national [...] or what it takes to incorporate in its legal order and the host state cannot call that choice into question'. But the underpinnings of the Court's bold stance on regulatory arbitrage, Sibony's conclusions suggest, may well lie in the fact that the costs of imposing the consequences of regulatory arbitrage on host states are indirect and remote and therefore escape the attention of the Court.

Not only is Centros still good law after 20 years, but, with one exception (Kornhaas $^{8}$ ), no explicit erosion of its authority has taken place via a more host-countryfriendly application of either the Gebhard test or the abuse doctrine. Yet, as Carsten Gerner-Beuerle, Federico Mucciarelli, Mathias Siems and Edmund Schuster demonstrate in their article, ${ }^{9}$ Member States never really needed to test the CJEU's willingness to go in that direction. They could rather resort to defining the lex societatis narrowly, i.e. to characterize some domestic rules affecting corporations, including (pseudo-)foreign ones, as part of other domains of their domestic law, and therefore applicable to all domestic businesses, wherever incorporated. As Gerner-Beuerle et al. put it, the Centros 'case law does not [...] place limits on the host state's ability to enact non-company law requirements which fulfil purposes similar or have effects comparable to those of core company law rules', with insolvency law being the most suitable candidate for the role, not least because its boundaries have been defined by EU secondary legislation. It is no coincidence that the only case explicitly circumscribing the scope of Centros is an insolvency law case, namely Kornhaas, on which Gerner-Beuerle et al., after accounting for the variety of scholarly views on its breadth as a precedent, provide their own balanced reading.

With the exception of the German GmbH-Gesetz provision analysed in Kornhaas, the many host country non-corporate law rules governing the corporate behaviour of non-domestic entities with their real seat therein have never been tested under Gebhard. In only two relatively early cases, Überseering and Inspire Art, ${ }^{10}$ have rules applying to pseudo-foreign entities been judged as illegitimate restrictions to free movement. In the meantime, all those non-corporate law restrictions have continued to apply to non-domestic EU companies. According to Gerner-Beuerle et al. this

\footnotetext{
7 Sibony (2019).

8 C-594/14 Simona Kornhaas v. Thomas Dithmar, ECLI:EU:C:2015:806.

9 Gerner-Beuerle et al. (2019).

10 C-208/00 Überseering [2002] ECR I-9919; C-167/01 Kamer van Koophandel en Fabrieken voor Amsterdam v. Inspire Art Ltd. [2003] ECR I-10155.
} 
phenomenon is part of the explanation for why so little regulatory arbitrage has been observed within the EU after a brief spike in the incorporation of continental European businesses as UK companies. ${ }^{11}$

While that phenomenon later proved to be more of a flash in the pan, ${ }^{12}$ as it unfolded it was worrisome to policymakers across continental Europe. In order to contain it, reforms were enacted to make domestic legal forms more attractive to local businesses, as Martin Gelter recounts. ${ }^{13}$ Throughout the continent, more business-friendly regulations replaced laws imposing minimum capital requirements and time-consuming, costly incorporation procedures.

Gelter's piece in this issue takes an empirical approach to answer the question of whether such instances of defensive regulatory competition had the desired effect of curbing pseudo-foreign incorporations in the UK. It does so by comparing the number of pseudo-foreign UK incorporations from Germany after the enactment of the relevant defensive regulatory competition reforms with the number of pseudoforeign UK incorporations from Austria in the same period. Because Germany and Austria had otherwise similar corporate laws, but Austria enacted a comparable reform only 6 years later, the decrease in 'German' UK incorporations and not in 'Austrian' UK incorporations in that period is evidence that, as policymakers desired, defensive regulatory competition reforms did have an impact on businesses' incorporation choices. The same treatment of data from Belgium and the Netherlands provides (weaker) evidence in the same direction.

Ever since Centros was published, legal scholars have compared the EU framework to the one in the US, where regulatory arbitrage and competition have been a key feature of the corporate law landscape and its evolution since the early 1880s. While the differences are significant, one commonality is that some states, such as California and New York, have also imposed some of their own corporate law rules on pseudo-foreign corporations. A recent incursion into corporate governance by California's legislature, known as SB 826, has been even bolder, imposing gender quotas on all companies, wherever incorporated, having their 'real seat' in that state. The contribution by Jill Fisch and Steven Davidoff Solomon aims to reconcile SB 826 with the internal affairs doctrine, which underpins company law arbitrage in the US. ${ }^{14}$ Their discussion echoes and complements the European debate on the boundaries of lex societatis: in their view, the internal affairs doctrine has to be understood as covering 'matters of shareholder economic interest'. Whenever the law has a social goal, rather than the goal of ensuring the maximization of firm value, it falls outside the domain of the internal affairs doctrine, no matter that its content (as in the case of SB 826) interferes with a core corporate governance mechanism such as board composition. Fisch and Davidoff Solomon notice how the stakeholder approach of SB 826 has much in common with the similar orientation of EU and Member States' company laws and, similarly to Gerner-Beuerle et al., point out that

\footnotetext{
11 See e.g. Gelter (2019).

12 Ringe (2013).

13 Gelter (2019).

14 Fisch and Davidoff Solomon (2019).
} 
such orientation may be part of the explanation for the lack of a Delaware effect from Centros. If SB 826 is part of a trend towards regulating companies and corporate governance with the aim of protecting external constituencies, ${ }^{15}$ then, as Fisch and Davidoff Solomon conclude, California's SB 826 may portend a movement of the United States towards European-style governance.

Minimum capital was Centros' main casualty of Member States' defensive regulatory competition reforms, but the legal capital doctrine, traditionally a centrepiece of the EU legislation on public companies, has remained so in the last two decades after surviving not only legal scholars' criticisms, but also a policy review by the European Commission. Eilís Ferran's article in this issue ${ }^{16}$ notices that Brexitwhich, as we write, looks likely to finally take place in the autumn of 2019-will create a natural experiment: how would national law evolve from the EU acquis in this area if Member States were free to deviate from it? To be sure, the UK is not just any other Member State when it comes to company law. It is fair to say that, even before Centros, it was already one of the jurisdictions least committed to the legal capital doctrine. But still, UK company law has always had a leadership role within the EU when it comes to corporate law: its example, if it ever moves away from the current legal capital regime, may inspire others.

The current political climate surrounding corporate law in the UK, especially after corporate defaults, such as BHS and Carillion, that involved large distributions of corporate assets to shareholders, may not be the most conducive to bold moves on these matters, as Ferran acknowledges. It thus appears likelier that, if any initiative is indeed taken, it will be about getting rid of UK company law's gold-plating provisions allowing distributions only of accumulated net realised profits. It would be quite ironic, but not necessarily surprising, if, post-Brexit, the newly conquered legislative sovereignty were used to fully align UK company law with EU harmonized rules.

More or less at the time when continental European businesses incorporated as UK companies after Centros, regulatory arbitrage became a reality in the insolvency law domain, albeit following a completely different dynamic. What prompted it was the EU's first attempt to provide a uniform jurisdictional and private international law framework for cross-border insolvencies, namely with the European Insolvency Regulation (EIR) of 2002. As Horst Eidenmüller recounts in his article for this issue, ${ }^{17}$ EIR's goal was exactly the opposite, namely to prevent forum shopping for insolvency proceedings by providing that such proceedings would be opened where the debtor company had its 'Centre of Main Interests' (COMI). Yet, the COMI is relatively easy to manipulate, and given the high stakes that insolvency proceedings involve, has in fact been relatively often manipulated since the EIR entered into force.

In addition to forum shopping for more favourable insolvency law regimes (and courts), creditors and debtors from all over the EU also found out that one

\footnotetext{
15 Pargendler (2016).

16 Ferran (2019).

17 Eidenmüller (2019).
} 
jurisdiction was providing a suitable legal environment for the restructuring of EU companies' finances, no matter where their COMIs were situated. That jurisdiction was, again, the UK. After documenting the UK's dominance in the market for debt restructuring services within the EU, Eidenmüller asks whether recent developments, namely the recast EIR, the European Restructuring Directive (ERD) and Brexit, will put an end to it. According to his analysis, while the recast EIR will not significantly hamper forum shopping and the ERD may curb regulatory competition with regard to pre-insolvency proceedings by providing for harmonized rules that will reduce the scope for innovation in this area of law, it is, unsurprisingly, Brexit that will have the greatest impact on regulatory arbitrage and competition in the law of corporate debt restructuring. The main reason is that 'restructuring decisions by English courts will no longer benefit from automatic recognition' in EU Member States. Unless other EU Member States, such as the Netherlands or Ireland, successfully replace the UK as an attractive jurisdiction for the effective handling of debt restructurings, European companies will be stuck with their own domestic framework, which may well be less effective (and efficient) than the UK one hitherto available to all.

As we have seen, Centros allowed EU companies to engage in company law arbitrage, and the EIR gave way to forum shopping for insolvency proceedings. Regulatory arbitrage is, of course, an opportunity, if not a strategy, for businesses in all

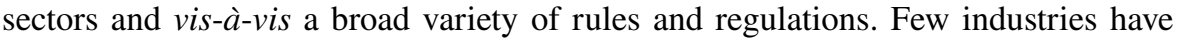
proven to be as keen as tech firms to exploit regulatory arbitrage opportunities, whether by using technology to make the choice of law easier and/or more profitable, or by capitalizing on the fact that they are usually startups and can therefore make regulatory choices as they develop their business, with no impediments from decisions made in a more or less distant past when regulatory arbitrage was either not available or not ripe for exploitation. Yet, as Elizabeth Pollman illustrates in her article for this issue, even tech firms do not fully exploit regulatory arbitrage opportunities, which prompts the question of why that is the case. ${ }^{18}$ She identifies three curbs to regulatory arbitrage: social licence (the fact that even tech firms are 'citizens' of our societies and cannot afford to alienate public opinion and their own employees by making regulatory arbitrage decisions that, while maximizing profits, may simply be socially unacceptable), bundling (the fact that it is not often easy to pick one regulatory regime without having other sets of rules also applying, which may not be optimal) and, more ominously, regulatory entrepreneurship (when breaking the law, and then pushing lawmakers into changing it, rather than choosing the 'desired' rules and regulations, is the tech firm's core strategy).

All in all, the seven articles published in this issue provide a number of insights on the relevance and implications of the regulatory arbitrage opportunities that Centros and other similar developments made available. They provide new insights into the important legacy of that CJEU decision and the changes in law and practice that it spurred.

${ }_{18}$ Pollman (2019). 


\section{References}

Eidenmüller H (2019) The rise and fall of regulatory competition in corporate insolvency law in the European Union. EBOR. https://doi.org/10.1007/s40804-019-00160-0 (in this issue)

Ferran E (2019) Revisiting legal capital. EBOR. https://doi.org/10.1007/s40804-019-00161-z (in this issue)

Fisch J, Davidoff Solomon S (2019) Centros, California's 'Women on Boards' Statute and the scope of regulatory competition. EBOR. https://doi.org/10.1007/s40804-019-00156-w (in this issue)

Gelter M (2019) Centros and defensive regulatory competition: some thoughts and a glimpse at the data. EBOR. https://doi.org/10.1007/s40804-019-00158-8 (in this issue)

Gerner-Beuerle C, Mucciarelli FM, Schuster E, Siems M (2019) The illusion of motion: corporate (im-) mobility and the failed promise of Centros. EBOR. https://doi.org/10.1007/s40804-019-00157-9 (in this issue)

Pargendler M (2016) The corporate governance obsession. J Corp Law 42:359-402

Pollman E (2019) Tech, regulatory arbitrage, and limits. EBOR. https://doi.org/10.1007/s40804-01900155-x (in this issue)

Ringe W (2013) Corporate mobility in the European Union-a flash in the pan? An empirical study on the success of lawmaking and regulatory competition. Eur Co Fin Law Rev 10:230-267

Sibony A-L (2019) Centros and the internal market. EBOR. https://doi.org/10.1007/s40804-019-00154 -y (in this issue)

Publisher's Note Springer Nature remains neutral with regard to jurisdictional claims in published maps and institutional affiliations. 